American University Washington College of Law

Digital Commons @ American University Washington College of Law

Competitive Price Discrimination: The Exercise of Market Power Without Anticompetitive Effects (Comment on Klein and Wiley)

Jonathan Baker

Follow this and additional works at: https://digitalcommons.wcl.american.edu/facsch_lawrev

Part of the Antitrust and Trade Regulation Commons, and the Law and Economics Commons 


\title{
COMPETITIVE PRICE DISCRIMINATION: THE EXERCISE OF MARKET POWER WITHOUT ANTICOMPETITIVE EFFECTS (COMMENT ON KLEIN AND WILEY)
}

\author{
JONATHAN B. BAKER*
}

A restaurant in a large city offers a $\$ 10$ discount on entrees for "early bird" customers who arrive before 6:00 p.m. This pricing policy could reflect the lower opportunity cost of serving customers during off-peak periods, when the table would otherwise go empty. But if early bird customers are more price sensitive than most, the policy could instead (or in addition) constitute economic price discrimination, by which the firm charges a higher price-cost margin to customers whose purchase decisions are, on average, less responsive to price. ' Another restaurant charges higher price-cost margins on wine than on food. If customers who drink wine with dinner linger longer at the table, this pricing policy could reflect the higher opportunity cost of serving a low-turnover customer group. But if customers who drink wine are generally willing to pay more for their meals than customers who abstain, then the policy could instead (or also) be understood as a method of price discrimination by metering the intensity of restaurant table usage. ${ }^{2}$

Klein and Wiley, in their important and thoughtful article, note the price discrimination possibilities in examples like these. ${ }^{3}$ Under the plausible but critical assumption that entry into the restaurant business in a large city is easy, price discrimination can be consistent with market

\footnotetext{
* Professor of Law, American University Washington College of Law, and Editorial Chair, Antitrust Law joumal. The author is grateful to Andy Gavil, Ben Klein, Steve Salop, and Dan Wall, and to the late Sherwin Rosen for discussions about price discrimination.

'Economic price discrimination, the subject of this comment, is not the same as price discrimination under the Robinson-Patman Act, and thus is not necessarily barred by that statute.

${ }^{2}$ Arbitrage is readily prevented by a restaurant's policy of forbidding patrons to bring in wine bottles purchased at liquor stores or by a restaurant's charge for corkage.

${ }^{3}$ Benjamin Klein \& John Shepard Wiley Jr., Competitive Price Discrimination as an Antitrust Justification for Intellectual Property Refusals to Deal, 70 ANTitrust L. J. 599 (2003).
} 
conduct that would reasonably be termed competitive. Part I of this comment highlights the critical role of ease of entry in identifying competitive price discrimination.

Competitive price discrimination is likely common. Klein and Wiley see the phenomenon as "normal and pervasive," ${ }^{4}$ and make the novel and intriguing suggestion that this possibility is relevant to understanding Kodak. ${ }^{5}$ In particular, their article highlights the possibility that a manufacturer's refusal to sell replacement parts to independent service organizations could serve to protect the manufacturer's effort to discriminate in price, using aftermarket service sales as a meter to measure buyer willingness to pay, which is thought to vary with intensity of use. This comment focuses on the implications of their suggested treatment of refusals to deal potentially motivated by an effort to discriminate in price for the antitrust analysis of price discrimination generally.

What should we make of the possibility of competitive price discrimination when enforcing the antitrust laws? How can the economic theory of competitive price discrimination be harmonized with the familiar categories of antitrust doctrine? Little attention has previously been given to these questions.

For Klein and Wiley, the possibility of competitive price discrimination means that antitrust law should not infer market power from the presence of any price discrimination. Part II of this comment takes a different view as to the legal implications of competitive price discrimination by distinguishing between market power and anticompetitive effect.

Price discrimination is properly understood as providing evidence of market power, as antitrust law has long recognized. After all, the practice of price discrimination shows that firms face a downward-sloping demand

\footnotetext{
${ }^{4}$ Klein \& Wiley, supra note 3, at 610. Whether or not price discrimination is pervasive, product differentiation surely is. Klein and Wiley connect the two concepts by suggesting that most, if not virtually all, differentiated product sellers discriminate in price. Whether or not that is true, the customer lock-in that may result from product differentiation helps ensure that price discrimination exists in free entry markets by providing a reason why a seller that increases some price above marginal cost can expect to sustain that price against the threat of cream-skimming entry. For a discussion of antitrust policy questions arising out of product differentiation, see Jonathan B. Baker, Product Differentiation Through Space and Time: Some Antitrust Policy Issues, 42 ANrrtroust Bull. 177 (1997).

5astman Kodak Co. v. Image Technical Servs., Inc., 504 U.S. 451 (1992). It is not necessary to decide whether Kodak's business practices reflected competitive price discrimination through metering (Klein and Wiley's view), rather than installed base opportunism facilitated by imperfect or asymmetric information (as the Court suggested) or a scheme to create market power by excluding rivals (another anticompetitive possibility), in order to evaluate the general significance of the possibility of competitive price discrimination for antitrust analysis. There is some question as to the strength of the evidence of price discrimination on the facts of $K o d a k$ itself, though. The plaintiff independent service
} 
curve and could potentially raise price by reducing output. Competitive price discrimination - the possibility that a market could be characterized simultaneously by price discrimination and free entry-could break the link between market power and anticompetitive effect, upon a demonstration that entry is easy. But that possibility does not break the link antitrust law correctly makes between price discrimination and market power.

Klein and Wiley's proposal that antitrust law should not infer market power from the presence of price discrimination is unnecessary to insulate competitive price discrimination from antitrust scrutiny. When entry is easy, proof of market power, through evidence of price discrimination or otherwise, is insufficient for inferring that firm conduct has an anticompetitive effect. In addition, any procompetitive benefits of price discrimination can be accounted for as a legitimate business justification.

The Klein-Wiley proposal is also unwise. It introduces a confusing distinction between market-power-in-economics and market-power-inantitrust and it risks insulating from antitrust liability firms engaged in price discrimination when discrimination, or practices that facilitate price discrimination, would harm competition.

\section{COMPETITIVE PRICE DISCRIMINATION}

When Klein and Wiley refer to market performance as competitive, they mean something different from textbook perfect competition. The firms engaged in competitive price discrimination face downward-sloping demand curves, not the flat demand curves of atomistic sellers. Competitive price discrimination is probably found most commonly in hightechnology markets and other industries with low marginal cost, high fixed costs, and some product differentiation. In such markets, it may be necessary for sellers to charge at least some customers prices in excess of marginal cost in order to make it profitable for firms to enter the market (by covering fixed costs) or stay there (to the extent the fixed costs are not sunk). ${ }^{6}$ Marginal cost pricing, the usual competitive benchmark, may thus be infeasible. ${ }^{7}$

organizations, which introduced evidence of price discrimination in the trial on remand, did not press that possibility as a basis for proving market power on appeal.

${ }^{6}$ Price discrimination and related practices like producing products in multiple versions are often a natural way to recover the high fixed costs of information technology. CARL. Shapiro \& Hal Varian, Information Rules: A Strategic Guide to the Network ECONOMY 18-91 (1999) (chapters on pricing information and versioning information).

${ }^{7}$ Klein and Wiley may be correct to question whether price discrimination is necessary to ensure a competitive equilibrium in many industries with high fixed costs (such as those in which intellectual property is important) and relatively low marginal costs. Klein \& Wiley, supra note 3 , at 617 n.34. They point out that marginal costs may not be low if 
What could "competitive price" mean when some prices would be expected to exceed marginal cost, as through price discrimination? In such markets, economists generally understand competitive prices to signify what would obtain in a market with "free entry." When entry is free, a potential entrant with an efficient cost structure (e.g., with costs no higher than those of incumbents) would enter so long as the average price it receives exceeds its average cost. ${ }^{9}$ Such an entrant does not fear that its additional output would depress the market price, making it unable to cover its sunk expenditures, nor worry that aggressive incumbent reactions to its entry would depress price further. Prices (or, more precisely, price-cost margins) may be high for some customers, but under competitive price discrimination, they are capped overall by the free entry constraint, which ensures that average price not exceed an efficient entrant's average cost. ${ }^{10}$

Relative to uniform pricing, price discrimination can harm buyers by allowing the seller to raise price to a group of buyers who would otherwise be charged less. To the extent these buyers are led to cut back on their purchases, moreover, price discrimination creates an allocative efficiency loss. Yet price discrimination could also benefit buyers and create an allocative efficiency gain if it encourages the seller to serve a group of previously unserved buyers by cutting price to that group. Accordingly,

distribution costs rise with output, and that product differentiation may be sufficient to prevent prices from falling to levels at which firms would not expect to be profitable even absent price discrimination. The analysis of competitive price discrimination in this Comment does not turn on whether price discrimination is necessary in order for competition to exist in markets in which firms have high fixed costs.

${ }^{8}$ On the possibility of price discrimination in free entry markets, see Mark Armstrong \& John Vickers, Competitive Price Discrimination, 32 RAND J. Econ. 579 (2001); Severin Borenstein, Price Discrimination in Free-Entry Markets, 16 RAND J. EcoN. 380 (1985); Einer Elhauge, Why Above-Cost Price Cuts to Drive Out Entrants Are Not Predatory-And the Implications for Defining Costs and Market Power, 112 Yale LJ. 681, 732-43 (2003); Thomas J. Holmes, The Effects of Third-Degree Price Discrimination in Oligopoly, 79 Am. Econ. Rev. 244 (1989); Andrea Shephard, Price Discrimination and Retail Configuration, 99 J. Pol. Econ. 30 (1991); Daniel F. Spulber, Regulation and Markets 544 -48 (1989); Lars Stole, Price Discrimi" nation in Competitive Environments (University of Chicago Graduate School of Business Working Paper, Nov. 7, 2001), available at http://gsblas.uchicago.edu/papers/hio-distrib. pdf; Lars Stole, Nonlinear Pricing and Oligopoly, 4 J. Econ. \& MGMT. STRATEgy 529 (1995).

${ }^{9}$ If an industry performs competitively by virtue of free entry, the industry's marginal cost of expanding output is the average cost for an efficient entrant. For this reason, the competitive price, which can be described as average cost pricing, can also be understood as a form of marginal cost pricing.

10 See generally Andrew I. Gavil, Whlliam E. Kovacic \& Jonathan B. Baker, Antrtrust Law in Perspectrve: Cases, Concepts and Problems in Competition Policy 713, 759-61, 817-18 \& 1090-91 (2002). Cf. In re Brand Name Prescription Drugs Antitrust Litig., 288 F.3d 1028 (7th Cir. 2002) (Posner, J.) (sellers of prescription drugs may charge different prices to different customers or different customer groups without exercising monopoly power). 
the welfare consequences of price discrimination in general are ambiguous, whether the test is consumer welfare or aggregate welfare (sum of consumer and producer surplus).

The ambiguous effects of price discrimination on economic welfare remain when firms have relatively high fixed costs, one setting in which competitive price discrimination may be common. Suppose, for example, that one software product, sold by a monopolist, has three classes of users. Most users would be willing to pay around $\$ 100$, but a small group of users would be willing to pay around $\$ 200$ and another small group would be willing to pay around $\$ 50$. Marginal cost is near zero. Suppose further that the typical member of the high-willingness-to-pay group would find attractive certain enhanced features of little use to most users, which the seller can include at negligible marginal cost, and the lowwillingness-to-pay group would be satisfied with a stripped-down version of the product, also inexpensive to create, while other users would not. The software seller can price discriminate by selling a "standard" version of its product for $\$ 100$, an "enhanced" version for $\$ 200$, and a "basic" version for $\$ 50$. In the event it were forced to charge a uniform priceif price discrimination were prohibited-it would most likely sell only the enhanced version and charge $\$ 100 .{ }^{11}$ If so, price discrimination both harms the enhanced users (who are charged an extra $\$ 100$ for features costing little), and benefits the basic users (who would not otherwise be served). ${ }^{12}$

The dynamic efficiency effects of allowing price discrimination also cannot be determined as a matter of theory, as the practice might enhance industry innovation incentives in some respects while reducing them in others. ${ }^{13}$ As Klein and Wiley emphasize, price discrimination may enhance the discriminating firm's incentives to innovate, by increasing the reward to the successful development of a new product or process. But policies that make price discrimination possible for the discriminating firm, such as the refusals to deal that allowed Kodak to meter its parts and service, according to Klein and Wiley, may simultaneously tend to discourage innovation by the price-discriminating firm's rivals, as by

\footnotetext{
${ }^{11}$ Because it is inexpensive to add the enhanced features, the monopolist finds it profitable to do so in order to attract the customer group that values those features.

${ }^{12}$ Moreover, if some enhanced users would only be willing to pay $\$ 180$ for the enhanced features (while most would pay more), those users would no longer purchase the product under price discrimination, creating an efficiency loss.

${ }^{13}$ Policies increasing incentives to innovate are generally a good thing because the social return to innovation is widely believed to exceed the private return substantially. In unusual circumstances, however, welfare could be reduced when innovation incentives are enhanced. This might occur, for example, if innovation incentives were already excessive, as in a wasteful patent race.
} 
raising the costs of innovation to competitors or limiting their potential reward. Under such circumstances, the net effect of the refusals to deal on industry-wide incentives to innovate is not obvious. For the industry as a whole, innovation incentives could be enhanced or reduced by allowing firms to engage in practices that facilitate price discrimination. Moreover when the refusals to deal are the acts of a leading firm, and innovation competition is winner-take-most or winner-take-all, as may occur in patent races or when network effects are important, industrywide innovation incentives are likely reduced on net. In such a setting, the leading firm's incentives would not be increased markedly by price discrimination beyond what the winner-take-most prize would already produce, while the refusal to deal would inhibit innovation by its fringe rivals substantially. ${ }^{14}$

Klein and Wiley tie price discrimination to product differentiation, suggesting that differentiated product sellers routinely discriminate in price. Much as with the practice of price discrimination, the welfare effects of investments in product differentiation are also ambiguous in theory. Firm investments in product differentiation commonly benefit buyers, by allowing firms to create a product or service with physical attributes, image, or location distinct from others available in the market. ${ }^{15}$ But when firms make such investments, some customers may find that the price they are charged increases by more than the extra value they receive from the new or improved product. ${ }^{16}$ If this occurs in a setting in which average prices are not constrained by free entry, that outcome may represent an anticompetitive effect that must be compared with the procompetitive benefits of increasing product variety and buyer choice. ${ }^{17}$

\footnotetext{
${ }^{14}$ See Jonathan B. Baker, Promoting Innovation Competition Through the Aspen/Kodak Rule, 7 Geo. Mason L. Rev. 495, 514-15 (1999).

15 Investments in product differentiation commonly valued by buyers may include firm spending "to create a greater variety of products, to improve . . brand names, to multiply ... retail outlets, or to undertake R\&D for product improvement." Klein \& Wiley, supra. note 3 , at 617 . To the extent firm investments in product differentiation alter the attributes, image, or location of an existing product, however, then they may also generate a welfare loss for those buyers who particularly value goods with the former characteristics.

16 For example, a firm's investments in product differentiation could make it more difficult or costly for rival firms to communicate the characteristics or their products to customers. (The firm might have purchased exclusive advertising rights on the most. important channels for reaching customers, for example, or obtained exclusive distribution rights to sell through the most significant and least replaceable dealers.) Under such circumstances, the firm's investments in differentiation might make firm demand less elastic through their exclusionary effect, allowing the firm to raise price by conferring market power.

17 Two familiar examples illustrate ways courts and enforcement agencies have made this trade-off. First, in merger analysis, a seller's acquisition of a rival selling a product
} 
While the welfare effects of price discrimination relative to uniform pricing are in general ambiguous as a matter of theory, it is reasonable to view competitive price discrimination (price discrimination with free entry) as a form of competition. After all, competitive price discrimination places a cap on average prices at a level consistent with competition from entrants, namely at the average cost of an efficient entrant, in a setting in which the usual competitive benchmark, marginal cost pricing, may be infeasible. So long as entry is easy, and the practices facilitating price discrimination do not harm competition, as by raising entry barriers or otherwise reducing competition by excluding actual or potential rivals, price discrimination is competitive, and not a harmful practice.

\section{PRICE DISCRIMINATION AND MARKET POWER IN ANTITRUST LAW}

Klein and Wiley recognize that price discrimination, whether competitive or otherwise, indicates that the firm involved faces a downwardsloping demand curve and, therefore, can exercise market power, as economists use the term..$^{18}$ But they resist deeming price discrimination in any guise-including price discrimination without free entry-to be market power under the antitrust laws for fear that practices facilitating competitive price discrimination will be found to violate the antitrust laws. Their approach is troublesome because it introduces a confusing distinction between market-power-in-economics and market-power-inantitrust $^{19}$ and because it risks insulating from antitrust liability firms

that is the closest substitute for many buyers removes a constraint on both firms' pricing. Such a merger harms competition absent an efficiency justification, ease of rival repositioning, or ease of entry. U.S. Department of Justice and Federal Trade Commission, Horizontal Merger Guidelines $\$ 2.21$ (1992, rev. 1997), reprinted in 4 Trade Reg. Rep. (CCH) \13,104. In monopolization cases, courts routinely treat the introduction of a new product that lowers cost, improves quality or performance, or is otherwise desirable to consumers as procompetitive. Even when the new product creates incompatibilities or otherwise raises costs to rivals, antitrust intervention is reserved for the rare situations in which the new product investment appears purely or largely aimed at restricting competition by preempt ing rivals, with little or no buyer benefit. E.g., United States v. Microsoft Corp., 253 F.3d 34, 58-78 (D.C. Cir. 2001); see generally Baker, supra note 4, at 192-94.

${ }^{18}$ Klein \& Wiley, supra note 3, at 625. Cf. George Stugler, The Organization of INDUSTRY 14 (1968) (describing "the absence of systematic price discrimination" as evidence of competition).

${ }^{19}$ The Klein-Wiley reading of the Supreme Court's discussion of monopolistic competition in the Cellophane case as rejecting the equation of market-power-in-economics with market-power-in-antitrust is far from compelled. Klein \& Wiley, supra note 3, at 629-30 (quoting United States v. E.I. du Pont de Nemours \& Co., 351 U.S. 377, 393 (1956) (Cellophane)). When the Court notes that the power over price possessed by a seller of branded consumer products need not constitute illegalmonopoly power, it may well instead merely be making a point highlighted in this Comment: that market power is only illegal if anticompetitive effect can be inferred from it. 
engaged in price discrimination when the high prices that may result from anticompetitive price discrimination, or practices that facilitate price discrimination, would harm competition..$^{20}$

The link between price discrimination and market power is well established in antitrust, both in the case law and in the writings of what Klein and Wiley appropriately describe as "a truly impressive list of scholars." 21 It is not necessary to break this link in order to avoid condemning competitive price discrimination, because determination of market power is not the end of the antitrust inquiry into the reasonableness of business conduct.

Market power is not the end of the antitrust inquiry for two reasons. First, under the relevant case law, the inference of anticompetitive effect from market power is not compelled. After all, market power is "but a 'surrogate for detrimental effects'." ${ }^{22}$ In modern antitrust analysis, proof of anticompetitive effect is part of the reasonableness inquiry under Sherman Act Section 1, relevant to the monopolization inquiry under Sherman Act Section 2, and implicit in the lessening of competition inquiry under Clayton Act Section 7. Anticompetitive effect can be established through direct evidence, such as proof that price rose or output declined, as well as inferred from proof of market power. ${ }^{23}$ Market power, in turn, can be established through direct evidence, including evidence as to demand elasticities or price discrimination, ${ }^{24}$ or else inferred from

\footnotetext{
26 Because antitrust forbids anticompetitive conduct, not status, the high prices that might result from price discrimination are not anticompetitive unless they have been achieved or maintained through anticompetitive conduct.

${ }^{21}$ Klein \& Wiley, supra note 3 , at 624 . Klein and Wiley modestly suggest that they are not the first to reject antitrust's longstanding view that price discrimination is evidence of market power. $1 d$. at 626. But the examples they provide are of commentators who accept that price discrimination shows the existence of market power without indicating its magnitude-a position also consistent with the view taken here that price discrimination provides evidence of market power without mandating the further inference of anticompetitive effect.

22 FTCv. Indiana Fed'n of Dentists, 476 U.S. 447, 461 (1986) (quoting 7 PHullp Areeda, ANTITRUST LAW $\uparrow 1511$ at 429 (1986)).

23 See Indiana Fed'n of Dentists, 476 U.S. at 460-61 (1986) (Sherman Act \$ 1); NCAA v. Bd. of Regents of the Univ. of Oklahoma, 468 U.S. 85, 110 \& 110 n.42 (1984) (Sherman Act \$ 1); United States v. Microsoft Corp., 253 F.3d 34, 51, 57-58 (D.C. Cir, 2001) (Sherman Act \$2); Re/Max Int'lv. Realty One, Inc., 173 F.3d 995, 1018-19 (6th Cir. 1999) (Sherman Act $\$ 2)$.

${ }^{24}$ Direct evidence of market power other than proof of price discrimination might include evidence from price comparisons across markets or over time, or evidence of demand elasticities. See generally Gavil, Kovacic \& BAKER, supra note 10, at 813-22. Price comparisons helped demonstrate market power in American Tobaco Co. v. United States, 328 U.S. 781 (1946) (prices rose while costs fell); in United States v. Addyston Pipe Eे Steel Co, 85 F. 271 (6th Cir. 1898), aff d, 175 U.S. 211 (1899) (higher prices in cities subject to market division agreement); and in Federal Trade Commission v. Staples, Inc, 970 F. Supp.
} 
proof of high market share. When market shares (or concentration) are used to demonstrate market power, and that showing of market power is used to prove anticompetitive effect, the method of proof of anticompetitive harm has been termed a "double inference." 25

While proof of market power often allows the inference of anticompetitive effect, that inference can be rebutted. In particular, a showing of ease of entry, which would indicate that any price discrimination is competitive, should be sufficient to rebut the inference of anticompetitive effect derived from the link between price discrimination and market power, ${ }^{26}$ just as ease of entry operates to rebut the inference of anticom-

1066 (D.D.C. 1997) (higher prices in cities and during time periods in which Staples was the only office superstore chain); Jonathan B. Baker, Econometric Analysis in F.T.C. v. Staples, 18 J. Pub. PoL. \& Mkтg. 11 (1999) (same).

Another type of direct evidence of market power involves proof of demand elasticities. See Jonathan B. Baker \& Daniel L. Rubinfeld, Empirical Methods in Antitrust Litigation: Review and Critique, 1 AM. J.L. \& ECON. 386, 406-27 (1999) (describing empirical methods of inferring the structure of demand, including demand elasticities). As Landes and Posner observed in their influential article on market power, if elasticity evidence is available, it can be used "to measure the firm's market power directly." William M. Landes \& Richard A. Posner, Market Power in Antitrust Cases, 94 HARv. L. REv. 937, 953 (1981) (showing how the elasticity of demand facing a dominant firm can be inferred from knowledge of the market elasticity of demand, firm market share, and the elasticity of supply of the competitive fringe). See also Gregory J. Werden, Demand Elasticities in Antitrust Analysis, 66 An'riTRUST L.]. 363 (1998). Demand elasticity evidence is relevant to the identification of market power because it bears on whether the economic force of buyer substitution would make unprofitable the effort of a firm or firms to raise price by reducing output. "The value of demand elasticity evidence for proving market power, even when products may be differentiated, is demonstrated by a retrospective look at the famous monopolization decision in United States v. Aluminum Co. of America, 148 F.2d 416 (2d Cir. 1945) (Alcoa). A careful empirical analysis of aluminum demand during the $1920 \mathrm{~s}$ and 1930 s supports Judge Learned Hand's decision to exclude secondary aluminum, recycled from scrap from the product market (and thus to assign Alcoa a $90 \%$ market share, rather than the $64 \%$ share it would have held had secondary aluminum been included). Valerie Y. Suslow, Estimating Monopoly Behavior with Competitive Recycling: An Application to Alcoa, 17 RAND J. EcoN. 389 (1986). The study concluded that the (firm) demand curve Alcoa had faced was not highly elastic because products were differentiated. Buyers of Alcoa's product, primary (virgin) aluminum, regarded secondary aluminum as only an imperfect substitute.

In principle, the inference of anticompetitive effect arising from these sources of direct evidence of market power can be rebutted through a showing of ease of entry, as with the comparable inference from proof of price discrimination. For example, if entry is easy, price differences over time could be consistent with competitive price discrimination over the business cycle. The firms earn higher margins when demand grows less elastic during booms, but the threat of entry constrains prices and incumbent firms do not expect to garner monopoly profits over the business cycle.

25 Gavil, Kovacic \& Baker, supra note 10, at 811.

${ }^{26}$ Michael Levine describes the extensive price discrimination practiced in the airline industry, and suggests that it may reflect competitive price discrimination. Michael $\mathrm{E}$. Levine, Price Discrimination Without Market Power, 19 YALE J. ON REG. 1, 21-25, 29-30 (2002). Whether this is so depends, as Levine points out, on "the degree to which the firm's total revenue is constrained by competition." Id. at 30 . For an argument as to why entry has not in the past supplied that constraint in some airline markets, see Jonathan B. Baker, 
petitive effect when market shares are high. ${ }^{27}$ But if entry is not easy, then price-discriminating sellers are not constrained to limit average price to the average cost of an efficient entrant. ${ }^{28}$ This situation could arise, for example, if the practices that facilitate price discrimination exclude entrants. ${ }^{29}$

Second, proof of market power through price discrimination does not end the antitrust inquiry as to anticompetitive effect even if price discrimination is not competitive, because price discrimination (or the practices that facilitate its exercise) could have a procompetitive effect in the market at issue, providing a business justification for the conduct. As a matter of antitrust doctrine, under the rule of reason, conduct does not violate the antitrust laws if the benefits to competition resulting from

Mavericks, Mergers, and Exclusion: Proving Coordinated Competitive Effects Under the Antitmust Laws, 77 N.Y.U. L. REv. 135, 170-71 (2002).

${ }^{27}$ A qualification as to the role of entry evidence is necessary with respect to proof of monopolization. Monopolization under Sherman Act Section 2 has two elements, (1) monopoly power and (2) a bad act to obtain or maintain it. This doctrinal rule tends in practice to channel another type of rebuttal evidence, evidence as to efficiencies, into the analysis of bad act. But when the rebuttal evidence involves ease of entry, and when monopoly power is demonstrated indirectly, through proof of high market share, Section 2 doctrine tends to channel this rebuttal evidence instead into the analysis of monopoly power. Rebuttal through ease of entry need not invariably be viewed as an aspect of the market power inquiry, however, even in monopolization law. When the rebuttal evidence involves ease of entry, and monopoly power is demonstrated directly, as through evidence of demand elasticities or price discrimination, entry evidence may more naturally be addressed through the analysis of bad act. Similarly, under Sherman Act Section 1 and Clayton Act Section 7, ease of entry is frequently treated as evidence that could rebut an inference of anticompetitive effect derived from proof of market power. This latter approach may become more common under Sherman Act Section 2 to the extent that monopoly power is more often demonstrated with direct evidence and to the extent the modern trend toward convergence in the antitrust analysis of reasonableness across doctrinal categories becomes more pronounced.

${ }^{28}$ In general, in oligopoly settings with price discrimination, the average price level would not necessarily be tethered to the competitive level (efficient entrant average cost) unless entry is free. Defendants might also seek to rebut the inference of anticompetitive effect from price discrimination by showing that the market is unconcentrated, suggesting that average prices would be constrained by the prospect of incumbent rival expansion (rather than the threat of entry). That conclusion appears most plausible when the market is highly unconcentrated, as that makes it most likely that every seller of differentiated products can be expected to face multiple close rivals, that sellers could not easily reach consensus and deter deviation from a coordinated outcome achievable through repeated interaction, and that any static oligopoly interaction among sellers is also limited. But not always: the restaurant hypothetical discussed at the end of Part II of this Comment provides an example of harm to competition from an agreement restricting the terms of price discrimination in an unconcentrated market with entry barriers.

${ }^{29}$ In the Klein-Wiley vision of Kodak, Kodak terminated independent service organization access to spare parts in order to make more effective metering of intensity of copier use, through high margins on parts and service. But entry into the copier industry might not be easy, for example, if those practices also meant that entrants would be required to develop their own service network. 
a legitimate business justification for the practices under review outweigh any anticompetitive effect. ${ }^{30}$

Some of these propositions can be illustrated by returning to the restaurant example. Suppose that many restaurants in a large city are discriminating in price through high markups on wine, using beverage sales as a metering device, and through "early bird" discounts on dinners purchased before $6: 00 \mathrm{p} . \mathrm{m}$. If an anticompetitive conspiracy among them were alleged, it may be tempting to call on the court to dismiss the case on the ground that the restaurant market is not concentrated, suggesting that the exercise of market power is unlikely and the observed price discrimination is competitive. This analysis could insulate some anticompetitive conduct from liability, however.

Suppose costs do not vary over the hours that dinner is served, and the restaurants set a common early bird discount at a level- $\$ 10$ offselected by explicit agreement of the membership of the city restaurant association. ${ }^{31}$ How should this agreement be reviewed under the Sherman Act? Perhaps it constitutes competitive price discrimination, allowing restaurants to cover their fixed costs. Under such circumstances, average prices would be capped at entrant average cost. But if entry is not easyassume, for example, that local health department regulations create an entry barrier-price discrimination may not be competitive and that benign conclusion may not hold. The price discrimination scheme could turn out to be a device for raising prices at regular dinner hours, not one for cutting prices for early customers. Analysis of entry conditions would be required, as would an analysis of the efficiency consequences of the discrimination itself (whether, for example, a uniform price regime would result in lower prices at regular dinner hours or, instead, generate higher prices during the early bird period) ${ }^{32}$ As this example suggests, whether the market power that results from price discrimination leads

\footnotetext{
930 Alternatively, if the defendants had a practical "less restrictive alternative" for achieving the procompetitive benefits at less threat of harm to competition, the conduct would be found unreasonable regardless of the relative magnitude of the benefits and harms.

${ }^{31}$ To bring the example closer to the Klein-Wiley refusal to deal framework, the agreement might be enforced by the threat that a restaurant offering a steeper discount would be expelled from the trade association, and trade association membership may allow the firms to lower costs (perhaps by serving as a group purchasing association).

3.2 If the restaurants had instead agreed not to open for dinner before 6:00 p.m., a court would likely condemn the agreement quickly as unreasonable. See In re Detroit Auto Dealers Ass'n, Inc., 955 F.2d 457 (6th Cir. 1992). Such an agreement could be understood as a way of preventing cheating on an agreement to raise price after $6: 00 \mathrm{p} . \mathrm{m}$. by removing some excess capacity (the empty tables just before the peak dinner hours) from the market. An agreement to charge lower prices before $6: 00 \mathrm{p} . \mathrm{m}$. could have a similar effect, preventing a cartel breakdown by allowing firms to shade the competitive price during periods when cheating is the most tempting.
} 
to an anticompetitive effect requires a competitive analysis, particularly of entry conditions.

\section{CONCLUSION}

The presence of price discrimination shows that firms face a downward sloping demand curve and thus could potentially raise price by reducing output. Such evidence is relevant to assessing market power. Yet price discrimination, and the practices that facilitate it, do not necessarily harm competition. When entry is free, price discrimination is not harmful and the outcome is reasonably termed competitive. Whether or not entry is easy, moreover, price discrimination can be beneficial. Accordingly, the presence of price discrimination alone should not be considered a conclusive basis for proof of anticompetitive effect.

Klein and Wiley suggest that courts should no longer infer market power from the presence of price discrimination. This proposal is both unnecessary and unwise. It is unnecessary to insulate competitive price discrimination from antitrust scrutiny because the inference of anticompetitive effect from proof of market power is rebuttable, as through a showing of ease of entry, and because the procompetitive benefits of the practice could count in justification of firm conduct. The proposal is also unwise because it introduces a confusing distinction between market-power-in-economics and market-power-in-antitrust and because it risks insulating from antitrust liability firms engaged in price discrimination when discrimination, or practices that facilitate price discrimination, would harm competition.

Courts should instead continue to follow the well-established analytical methodology of considering all relevant evidence of market power, direct and indirect alike, when market power is the issue, treating the inference of anticompetitive effect from proof of market power as rebuttable, and accounting for legitimate business justifications in determining whether a practice with some anticompetitive effect is unreasonable. If this analytic approach is applied with attention to the potential beneficial effects of competitive price discrimination that Klein and Wiley have usefully called to our attention, courts and enforcement agencies will be unlikely to mistake competitive price discrimination for an unreasonable business practice. 